\title{
Experimental Evidence for a Demographic Cline in Panstrongylus megistus Populations
}

\section{Silvia E Barbosa/*, Rodrigo PP Soares*, Herton HR Pires, Liléia Diotaiuti/ ${ }^{+}$}

Laboratório de Triatomíneos e Epidemiologia da Doença de Chagas, Centro de Pesquisas René Rachou-Fiocruz, Caixa Postal 1743, 30190-002 Belo Horizonte, MG, Brasil *Departamento de Parasitologia, ICB, UFMG, Belo Horizonte, MG, Brasil

The population biology of three populations of Panstrongylus megistus was compared to determine possible influence on the behaviour and epidemiological importance of this species. The results demonstrated differences in terms of egg eclosion time, nymphal mortality and development rates, and feeding and defaecation rates. These differences appeared to follow a geographical cline, primarily reflecting different degrees of adaptation to domestic habitats.

Key words: Panstrongylus megistus - populations - biological characterization

Pantrongylus megistus (Burmeister, 1835) (Hemiptera, Reduviidae) is currently considered the principal vector of Trypanosoma cruzi in the eastern, southern and some northeastern states of Brasil. In Bahia, it is well adapted to living in houses and peridomestic habitats but its existence in sylvatic foci has not been proven. By contrast, in the southeastern states it can be found in sylvatic and domestic habitats, while in the south it is predominantly sylvatic (Pessoa 1962, Forattini 1980, Schofield 1994). Because of these differences, Pessoa (1962) proposed the existence of two subspecies of $P$. megistus, one sylvatic and the other domestic, but there is no further evidence to support such an idea (Dórea et al. 1982, Barbosa et al. 1998). Barbosa et al. (1999) found differences in the electrophoretic profiles of the salivary proteins of different $P$. megistus populations, but suggested that such differences had no genetic base because other characters of these populations showed no relationship with their sylvatic or domestic origin (Barbosa et al. 1998).

It is possible that $P$. megistus originated as a sylvatic species in the original Atlantic forest regions of Brasil (Forattini 1980) with domestic

\footnotetext{
This work was supported by Capes, Fapemig, Centro de Pesquisas René Rachou-Fiocruz and benefited from additional support throgh the ECLAT network.

${ }^{+}$Corresponding author. Fax: +55-31-3295.3115

E-mail: diotaiuti@cpqrr.fiocruz.br

Received 22 November 2000

Accepted 28 March 2001
}

populations arising through colonization of early post-colonial settlements. A similar process may have ocurred in the northeast, with the original sylvatic populations subsequently eliminated by agricultural development, or it may be that the domestic northeastern populations were transported from the south in association with human migrations. Either way, a series of population adaptations may be expected, associated with the transition from sylvatic to domestic habitats (Schofield 1988), whereby the domestic populations may be expected to be more efficient in resource utilization compared to their sylvatic conspecifics (Schofield et al. 1999). The present work was designed to examine this hypothesis, by comparing the life-cycle and feeding dynamics of $P$. megistus populations originating from different areas.

Specimens of $P$. megistus were collected from Campo Formosa, Bahia (BA - peridomiciliary populations), from Florianópolis, Santa Catarina ( $\mathrm{SC}$ - peridomiciliary populations), and from Belo Horizonte, Minas Gerais (MG - intradomiciliary populations). They were maintained under constant conditions in the insectary $\left(27^{\circ} \mathrm{C}\right.$ and $60 \%$ $\mathrm{RH}+10 \%)$ and allowed to feed on anaesthetised albino mice (SwissWebster) for $1 \mathrm{~h}$ twice per week. Eggs were collected, and after eclosion 801 st instar nymphs of each of the three populations were maintained for comparative cohort studies. Blood ingestion and the rate of defaecation per instar was estimated separately using batches of 30 nymphs of each instar from each colony.

Under these conditions, egg development time differed significantly between the populations, with those of BA averaging 21 days compared to an 18 
day average for the MG and SC populations. Overall, the SC populations developed most rapidly, completing their egg-to-adult development in a mean of 138 days, compared to 168 days for the BA population and 201 days for the MG population (Table I). However, overall mortality was higher in the SC and MG populations $(13.8 \%$ and $11.1 \%$, respectively) compared to the BA population $(2.5 \%)$. During development, insects of the BA population took an average of 15 bloodmeals with an overall weight gain of 12.2 times initial weight. In contrast, insects of the MG population took an average of 16 bloodmeals with an overall weight gain of 11.5 times, and the SC population took and average of 18 bloodmeals with an overall weight gain of 10.9 times (Tables II, III). The defaecation rate followed a similar pattern, with the BA insects showing an average of eight faecal drops after each meal, followed by the MG insects with seven and the SC with six (Table IV).

\section{TABLE I}

Mean time (days) that triatomines of populations of Minas Gerais, Bahia and Santa Catarina remained in each developmental phase before reaching the adult stage $\left(27^{\circ} \mathrm{C}, 60 \pm 10 \% \mathrm{RH}\right)$

\begin{tabular}{|c|c|c|c|c|c|c|c|c|c|}
\hline \multirow{2}{*}{$\begin{array}{l}\text { Developmental } \\
\text { phase }\end{array}$} & \multicolumn{3}{|c|}{ Minas Gerais } & \multicolumn{3}{|c|}{ Bahia } & \multicolumn{3}{|c|}{ Santa Catarina } \\
\hline & Min & Max & $\bar{X} \pm S$ & Min & Max & $\bar{X} \pm S$ & Min & Max & $\bar{X} \pm S$ \\
\hline Egg & 17 & 22 & $18.3 \pm 0.9(72)$ & 12 & 23 & $20.6 \pm 2.2(79)$ & 9 & 21 & $18.0 \pm 1.5(80)$ \\
\hline First & 12 & 82 & $26.2 \pm 14.7(72)$ & 11 & 83 & $20.4 \pm 9.3(79)$ & 12 & 36 & $18.3 \pm 4.8(80)$ \\
\hline Second & 13 & 78 & $33.5 \pm 16.7(71)$ & 12 & 46 & $22.8 \pm 8.2(78)$ & 10 & 34 & $16.6 \pm 4.4(75)$ \\
\hline Third & 15 & 106 & $31.0 \pm 16.5(68)$ & 15 & 91 & $27.0 \pm 11.3(77)$ & 13 & 36 & $18.9 \pm 3.9(74)$ \\
\hline Fourth & 19 & 91 & $34.8 \pm 15.4(67)$ & 15 & 147 & $33.8 \pm 18.5(77)$ & 15 & 49 & $25.2 \pm 6.4(74)$ \\
\hline Fifth & 25 & 122 & $56.8 \pm 20.9$ & 18 & 94 & $43.5 \pm 10.8(77)$ & 22 & 69 & $40.8 \pm 8.3(69)$ \\
\hline First-adult & 127 & 316 & $201.2 \pm 45.7$ & 129 & 298 & $168.1 \pm 34.8$ & 100 & 174 & $137.9 \pm 14.5$ \\
\hline
\end{tabular}

Values in parentheses represent the number of insects in each phase of development.

TABLE II

Weight increase of Panstrongylus megistus in relation to the initial weight, following the first blood meal and after the final moult $\left(27^{\circ} \mathrm{C}, 60 \pm 10 \% \mathrm{RH}\right)$

\begin{tabular}{|c|c|c|c|c|c|c|c|c|c|}
\hline \multirow{2}{*}{$\begin{array}{l}\text { Developmental } \\
\text { stage }(n=30)\end{array}$} & \multicolumn{3}{|c|}{ Minas Gerais } & \multicolumn{3}{|c|}{ Bahia } & \multicolumn{3}{|c|}{ Santa Catarina } \\
\hline & Min & Max & $\bar{X} \pm S$ & Min & Max & $\bar{X} \pm S$ & Min & Max & $\bar{X} \pm S$ \\
\hline First & 0.7 & 5.7 & $3.1 \pm 1.3$ & 0.8 & 7.6 & $4.1 \pm 1.9$ & 0.4 & 6.7 & $2.8 \pm 1.6$ \\
\hline Second & 1.0 & 6.5 & $3.2 \pm 1.3$ & 0.4 & 6.8 & $2.9 \pm 1.6$ & 0.5 & 7.3 & $3.1 \pm 1.3$ \\
\hline Third & 0.5 & 4.1 & $2.1 \pm 0.9$ & 0.6 & 5.0 & $2.5 \pm 0.9$ & 0.3 & 6.1 & $2.2 \pm 1.4$ \\
\hline Fourth & 0.4 & 3.4 & $1.6 \pm 0.8$ & 0.3 & 4.1 & $1.5 \pm 0.9$ & 0.5 & 3.2 & $1.7 \pm 0.7$ \\
\hline Fifth & 0.3 & 2.7 & $1.5 \pm 0.7$ & 0.2 & 3.5 & $1.3 \pm 0.9$ & 0.1 & 2.3 & $1.1 \pm 0.6$ \\
\hline Females & 7.6 & 14.6 & $11.5 \pm 2.4$ & 7.1 & 17.6 & $12.0 \pm 3.6$ & 7.1 & 20.4 & $10.9 \pm 3.2$ \\
\hline Males & 8.4 & 16.0 & $11.6 \pm 2.2$ & 6.0 & 19.3 & $12.4 \pm 3.0$ & 7.3 & 18.6 & $10.9 \pm 3.4$ \\
\hline Total & 7.6 & 16.0 & $11.5 \pm 2.2$ & 6.0 & 19.3 & $12.2 \pm 3.2$ & 7.1 & 20.4 & $10.9 \pm 3.2$ \\
\hline
\end{tabular}

Ratio: final weight/initial weight

TABLE III

Number of blood meals taken per stage during throughout the life cycle of three population of Panstrongylus megistus $\left(27^{\circ} \mathrm{C}, 60 \pm 10 \% \mathrm{RH}\right)$

\begin{tabular}{|c|c|c|c|c|c|c|c|c|c|}
\hline \multirow{2}{*}{$\begin{array}{l}\text { Developmental } \\
\text { stage }(n=30)\end{array}$} & \multicolumn{3}{|c|}{ Minas Gerais } & \multicolumn{3}{|c|}{ Bahia } & \multicolumn{3}{|c|}{ Santa Catarina } \\
\hline & Min & Max & $\bar{X} \pm S$ & Min & Max & $\bar{X} \pm S$ & Min & Max & $\bar{X} \pm S$ \\
\hline First & 1 & 4 & $1.5 \pm 0.7$ & 1 & 3 & $15 \pm 0.6$ & 1 & 3 & $1.8 \pm 0.6$ \\
\hline Second & 1 & 5 & $2.4 \pm 10$ & 1 & 3 & $2.0 \pm 0.7$ & 2 & 5 & $3.1 \pm 0.9$ \\
\hline Third & 2 & 5 & $3.0 \pm 0.9$ & 2 & 4 & $2.6 \pm 0.7$ & 2 & 5 & $3.2 \pm 0.9$ \\
\hline Fourth & 2 & 7 & $3.9 \pm 1.2$ & 2 & 6 & $3.5 \pm 1.1$ & 2 & 8 & $4.2 \pm 1.6$ \\
\hline Fifth & 2 & 10 & $5.2 \pm 2.1$ & 3 & 7 & $5.3 \pm 1.2$ & 2 & 9 & $5.9 \pm 1.4$ \\
\hline Total & 11 & 27 & $16.0 \pm 3.5$ & 10 & 18 & $14.9 \pm 2.0$ & 15 & 23 & $18.1 \pm 1.9$ \\
\hline
\end{tabular}


TABLE IV

Number of defaecations immediately after blood meal intake for the different nymphal instars of three populations of Panstrongylus megistus $\left(27^{\circ} \mathrm{C}\right.$ and $\left.60 \pm 10 \% \mathrm{RH}\right)$

\begin{tabular}{|c|c|c|c|c|c|c|c|c|c|}
\hline \multirow{3}{*}{ Instar } & \multicolumn{9}{|c|}{ Mean of defaecations per engorged insect } \\
\hline & \multicolumn{3}{|c|}{ Minas Gerais } & \multicolumn{3}{|c|}{ Bahia } & \multicolumn{3}{|c|}{ Santa Catarina } \\
\hline & Min & $\operatorname{Max}$ & $\bar{X} \pm S$ & Min & $\operatorname{Max}$ & $\bar{X} \pm S$ & Min & Max & $\bar{X} \pm S$ \\
\hline First & - & 2 & $0.9 \pm 0.7$ & - & 2 & $0.9 \pm 0.6$ & - & 2 & $0.4 \pm 0.5$ \\
\hline Second & - & 3 & $1.0 \pm 0.9$ & - & 2 & $1.1 \pm 0.9$ & - & 2 & $0.7 \pm 0.7$ \\
\hline Third & - & 3 & $1.4 \pm 0.9$ & - & 4 & $1.3 \pm 0.9$ & - & 2 & $1.3 \pm 0.7$ \\
\hline Fourth & - & 4 & $2.1 \pm 1.1$ & - & 5 & $1.9 \pm 1.2$ & - & 4 & $2.0 \pm 1.0$ \\
\hline Fifth & - & 5 & $1.9 \pm 1.4$ & - & 5 & $2.5 \pm 1.2$ & - & 4 & $1.9 \pm 1.1$ \\
\hline Total & - & 14 & $7.3 \pm 2.2$ & - & 11 & $7.8 \pm 2.0$ & - & 11 & $6.4 \pm 1.8$ \\
\hline
\end{tabular}

These results, although preliminary, are suggestive of a geographical cline. The population of southernmost origin (SC) developed faster but required more bloodmeals and suffered higher mortality in the process. The northernmost population (BA) developed more slowly but required fewer bloodmeals and suffered least mortality. The geographically intermediate MG population was also intermediate in most of the measured parameters, except for overall development time. In terms of resource utilization, the BA population can be seen to be the most efficient of the three, followed by the MG and SC populations. Of particular interest therefore, is the average weight gain of the BA population, which was significantly greater than that of the other two populations. Morphometric analysis reflects this pattern, with the BA populations generally showing larger females that lay larger and heavier eggs than the other two (Barbosa 1998). Such results can be interpreted as revealing different demographic strategies (sensu Rabinovich 1974) with the BA populations showing strongest $K$-selection, compared to weaker $K$-selection in the SC populations and intermediate $K$-selection in the MG populations.

Although the apparent demographic cline reflects the geographical origin of the three populations along a N-S axis, it also reflects their different levels of adaptation to domestic habitats. The most $K$-selected population (BA) was from a region where sylvatic populations are unknown; the intermediate (MG) population originated from an area where sylvatic, peridomestic, and domestic populations are known, whereas the SC population came from an area where fully domestic populations have not been reported. This experimental study thus provides evidence in support of the idea that domestication in Triatominae can lead to increased $K$-selection associated with greater efficiency in resource utilization (Schofield et al. 1999).

\section{ACKNOWLEDGMENTS}

To Dr Christopher John Schofield for the critical revision.

\section{REFERENCES}

Barbosa SE 1998. Biossistemática de Três Diferentes Populações Brasileiras de Panstrongylus megistus (Burmeister, 1835), MSc Thesis, Universidade Federal de Minas Gerais, Belo Horizonte, 154 pp.

Barbosa SE, Diotaiuti L, Soares RPP, Pereira MH 1999. Differences in saliva composition among three Brazilian populations of Panstrongylus megistus (Hemiptera, Reduviidae). Acta Trop 72: 91-98.

Barbosa SE, Soares RPP, Pires HHR, Melo MD, Pimenta PFP, Margonari C, Dujardin JP, Catalá SS, Panzera F, Romanha AJ, Pereira MH, Diotaiuti L 1998. Biossistemática de Panstrongylus megistus (Burmeister, 1835). Rev Soc Bras Med Trop 31: 2931.

Dórea RCC, Póvoa MM, Miles MA, Souza AAA, Barata JM 1982. Eletroforese de enzimas para estudo de triatomíneos com referência especial a subpopulações de P. megistus. Rev Bras Biol 42: 521-526.

Forattini OP 1980. Biogeografia, origem e distribuição da domiciliação de triatomíneos no Brasil. Rev Saúde Pública 14: 265-299.

Pessoa SB 1962. Domiciliação de triatomíneos e epidemiologia da doença de Chagas. Arq Hig Saúde Públ 27: 161-171.

Rabinovich JE 1974. Demographic strategies in animal populations: a regression analysis. In FB Golloy, E Medina (eds), Tropical Ecological Systems, Springer Verlag, New York, p. 19-40.

Schofield CJ 1988. The biosystematics of Triatominae. In MW Service, Biosystematics of Haematophagous Insects, Systematics Association, Special Volume 37, Clarenden Press, Oxford, p. 284-312.

Schofield CJ 1994. Triatominae: Biologia y Control, Eurocommunica Publications, West Sussex, $80 \mathrm{pp}$.

Schofield CJ, Diotaiuti L, Dujardin JP 1999. The process of domestication in Triatominae. Mem Inst Oswaldo Cruz 94 (Suppl.1): 375-378. 
776 Demographic Cline in P. megistus - Silvia E Barbosa et al. 